\title{
Front Matter: Volume 8811
}

, "Front Matter: Volume 8811," Proc. SPIE 8811, Physical Chemistry of Interfaces and Nanomaterials XII, 881101 (25 September 2013); doi: $10.1117 / 12.2034140$

SPIE Event: SPIE NanoScience + Engineering, 2013, San Diego, California, United SPIE. States 


\section{PROCEEDINGS OF SPIE}

\section{Physical Chemistry of Interfaces and Nanomaterials XII}

Natalie Banerji

Carlos Silva

Editors

25-28 August 2013

San Diego, California, United States

Sponsored and Published by

SPIE 
The papers included in this volume were part of the technical conference cited on the cover and title page. Papers were selected and subject to review by the editors and conference program committee. Some conference presentations may not be available for publication. The papers published in these proceedings reflect the work and thoughts of the authors and are published herein as submitted. The publisher is not responsible for the validity of the information or for any outcomes resulting from reliance thereon.

Please use the following format to cite material from this book:

Author(s), "Title of Paper," in Physical Chemistry of Interfaces and Nanomaterials XII, edited by Natalie Banerji, Carlos Silva, Proceedings of SPIE Vol. 8811 (SPIE, Bellingham, WA, 2013) Article CID Number.

ISSN: 0277-786X

ISBN: 9780819496614

Published by

SPIE

P.O. Box 10, Bellingham, Washington 98227-0010 USA

Telephone +1 3606763290 (Pacific Time) · Fax +1 3606471445

SPIE.org

Copyright (C) 2013, Society of Photo-Optical Instrumentation Engineers.

Copying of material in this book for internal or personal use, or for the internal or personal use of specific clients, beyond the fair use provisions granted by the U.S. Copyright Law is authorized by SPIE subject to payment of copying fees. The Transactional Reporting Service base fee for this volume is $\$ 18.00$ per article (or portion thereof), which should be paid directly to the Copyright Clearance Center (CCC), 222 Rosewood Drive, Danvers, MA 01923. Payment may also be made electronically through CCC Online at copyright.com. Other copying for republication, resale, advertising or promotion, or any form of systematic or multiple reproduction of any material in this book is prohibited except with permission in writing from the publisher. The CCC fee code is 0277-786X/13/\$18.00.

Printed in the United States of America.

Publication of record for individual papers is online in the SPIE Digital Library.

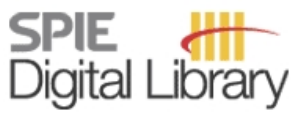

SPIEDigitalLibrary.org

Paper Numbering: Proceedings of SPIE follow an e-First publication model, with papers published first online and then in print and on CD-ROM. Papers are published as they are submitted and meet publication criteria. A unique, consistent, permanent citation identifier (CID) number is assigned to each article at the time of the first publication. Utilization of CIDs allows articles to be fully citable as soon as they are published online, and connects the same identifier to all online, print, and electronic versions of the publication. SPIE uses a six-digit CID article numbering system in which:

- The first four digits correspond to the SPIE volume number.

- The last two digits indicate publication order within the volume using a Base 36 numbering system employing both numerals and letters. These two-number sets start with 00, 01, 02, 03, 04, $05,06,07,08,09,0 A, 0 B \ldots$ OZ, followed by 10-1Z, 20-2Z, etc.

The CID Number appears on each page of the manuscript. The complete citation is used on the first page, and an abbreviated version on subsequent pages. Numbers in the index correspond to the last two digits of the six-digit CID Number. 


\section{Contents}

vii Conference Committee

\section{NANOSYSTEMS IN BIOLOGY AND GAS SENSING}

881102 Single-molecule microscopy using tunable nanoscale confinement (Invited Paper) [8811-1]

C. M. J. McFaul, J. Leith, B. Jia, F. Michaud, A. Arsenault, A. Martin, D. Berard, S. Leslie, McGill Univ. (Canada)

$881106 \mathrm{H}_{2} \mathrm{O} / \mathrm{D}_{2} \mathrm{O}$ exchange in the presence of $\mathrm{CO}$ over $\mathrm{SnO}_{2}$ nanomaterials: operando DRIFTS and resistance study for gas sensor applications [881 1-5]

R. G. Pavelko, J.-K. Choi, Kyushu Univ. (Japan); A. Urakawa, Institute of Chemical Research of Catalonia (Spain); M. Yuasa, T. Kida, K. Shimanoe, N. Yamazoe, Kyushu Univ. (Japan)

\section{HYBRID AND INORGANIC SYSTEMS FOR PHOTONICS AND LIGHT CONVERSION I}

881108 Photoinduced processes in lead iodide perovskite solid-state solar cells [8811-7] A. Marchioro, J. C. Braver, J. Teuscher, M. Grätzel, J.-E. Moser, École Polytechnique Fédérale de Lausanne (Switzerland)

HYBRID AND INORGANIC SYSTEMS FOR PHOTONICS AND LIGHT CONVERSION II

$88110 \mathrm{C}$ In-situ investigation of adsorption of dye and coadsorbates on $\mathrm{TiO}_{2}$ films using QCM-D, fluorescence and AFM techniques [8811-11]

H. A. Harms, N. Tétreault, K. Voïtchovsky, F. Stellacci, M. Grätzel, École Polytechnique

Fédérale de Lausanne (Switzerland)

\section{NANOSTRUCTURES AND NANOWIRES}

8811 0J Probing the transient fate of $\mathrm{C}-\mathrm{N}$ bonding in hydrazine-treated carbon nanotubes by synchrotron photoelectron spectroscopy [8811-18]

P.-C. Wang, National Tsing Hua Univ. (Taiwan); Y.-C. Liao, National Tsing Hua Univ. (Taiwan) and National Synchrotron Radiation Research Ctr. (Taiwan); L.-H. Liu, National Tsing Hua Univ. (Taiwan); Y.-L. Lai, Y.-C. Lin, National Synchrotron Radiation Research Ctr. (Taiwan); C.-Y. Su, National Tsing Hua Univ. (Taiwan); Y.-J. Hsu, National Synchrotron Radiation Research Ctr. (Taiwan) 
8811 ON Photoinduced charge transfer across an organic/contact interface: polaronic state spectroscopy [8811-22]

A. L. Carver, K. Fernando, H. M. Shah, S. Kolli, B. Abeyweera, B. W. Alphenaar, Univ. of Louisville (United States); M. Menon, Univ. of Kentucky (United States); S. Lisenkov, Univ. of South Florida (United States)

\section{CHARGE TRANSPORT IN ORGANIC ELECTRON DEVICES}

8811 OS Characteristics of P3HT:PCBM bilayer middle-contact transistors incorporating a conjugated polyelectrolyte layer (Invited Paper) [881 1-27]

G. J. Chae, J. H. Seo, Dong-A Univ. (Korea, Republic of)

8811 OU Quantum interference in EGaln based tunneling junctions [8811-29]

D. Fracasso, R. C. Chiechi, Univ. of Groningen (Netherlands)

8811 OW Effect of film nanostructure on in-plane charge transport in organic bulk heterojunction materials [8811-31]

E. Danielson, The Univ. of Texas at Austin (United States); Z.-E. Ooi, A*STAR Institute of Materials Research and Engineering (Singapore); A. Dodabalapur, The Univ. of Texas at Austin (United States)

FUNDAMENTAL MATERIALS PROPERTIES IN ORGANIC PHOTOVOLTAIC DEVICES II

881116 Photovoltaics at the nanoscale [8811-41]

Z. Schumacher, McGill Univ. (Canada); J. Topple, McGill Univ. (Canada) and Chipworks (Canada); A. Tekiel, P. Grütter, McGill Univ. (Canada)

881117 Impact of methanol top-casting or washing on the polymer solar cell performance [8811-42]

O. Synooka, Technische Univ. IImenau (Germany); F. Kretschmer, M. D. Hager,

U. S. Schubert, Friedrich-Schiller-Univ. Jena (Germany); G. Gobsch, H. Hoppe, Technische

Univ. Ilmenau (Germany)

\section{CHARGE GENERATION IN ORGANIC SOLAR CELLS I}

881119 Control of light absorption in organic solar cells using semi-transparent metal electrodes (Invited Paper) [881 1-44]

S. Neutzner, J. van de Groep, A. A. Bakulin, H. J. Bakker, FOM Institute AMOLF (Netherlands)

8811 1D Ultrafast exciton dissociation at donor/acceptor interfaces (Invited Paper) [8811-48] G. Grancini, D. Fazzi, M. Binda, Istituto Italiano di Tecnologia (Italy); M. Maiuri, Politecnico di Milano (Italy); A. Petrozza, L. Criante, S. Perissinotto, Istituto Italiano di Tecnologia (Italy); H.-J. Egelhaaf, BELECTRIC OPV GmbH (Germany); D. Brida, G. Cerullo, Politecnico di Milano (Italy); $G$. Lanzani, Istituto Italiano di Tecnologia (Italy) 
$8811 \mathrm{lF}$ Charge generation in polymer:perylene diimide blends probed by Vis-NIR broadband transient absorption pump-probe spectroscopy (Invited Paper) [8811-50]

D. Gehrig, I. A. Howard, V. Kamm, C. Dyer-Smith, F. Ełzold, F. Laquai, Max Planck Institute for Polymer Research (Germany)

\section{CHARGE GENERATION IN ORGANIC SOLAR CELLS III}

$8811 \mathrm{1H}$ Multi-THz spectroscopy of mobile charge carriers in P3HT:PCBM on a sub-100 fs time scale (Invited Paper) [881 1-52]

D. G. Cooke, McGill Univ. (Canada); F. C. Krebs, P. U. Jepsen, Technical Univ. of Denmark (Denmark)

$88111 \mathrm{~J}$ Long-lived photoexcitations in intercalated, partially and predominantly non-intercalated polymer:fullerene blends [8811-59]

F. Dou, Univ. de Montréal (Canada) and Beijing Univ. of Technology (China);

E. Buchaca-Domingo, Imperial College London (United Kingdom); M. Sakowicz, Univ. de Montréal (Canada); X. Zhang, Beijing Univ. of Technology (China); N. Stingelin, Imperial College London (United Kingdom); C. Silva, Univ. de Montréal (Canada)

Author Index 
Proc. of SPIE Vol. $8811881101-6$

Downloaded From: https://www.spiedigitallibrary.org/conference-proceedings-of-spie on 26 Apr 2023 Terms of Use: https://www.spiedigitallibrary.org/terms-of-use 


\title{
Conference Committee
}

\author{
Symposium Chairs
}

Satoshi Kawata, Osaka University (Japan)

Manijeh Razeghi, Northwestern University (United States)

Symposium Cochairs

David L. Andrews, University of East Anglia Norwich (United Kingdom)

James G. Grote, Air Force Research Laboratory (United States)

Conference Chairs

Natalie Banerji, Ecole Polytechnique Fédérale de Lausanne (Switzerland)

Carlos Silva, Université de Montréal (Canada)

Conference Program Committee

John B. Asbury, The Pennsylvania State University (United States)

Jenny Clark, University of Cambridge (United Kingdom)

Oliver L. A. Monti, The University of Arizona (United States)

Oleg V. Prezhdo, University of Rochester (United States)

Sergei Tretiak, Los Alamos National Laboratory (United States)

Session Chairs

1 Nanosystems in Biology and Gas Sensing

Delphine Bouilly, Université de Montréal (Canada)

2 Hybrid and Inorganic Systems for Photonics and Light Conversion I

Ji-Seon Kim, Imperial College London (United Kingdom)

3 Hybrid and Inorganic Systems for Photonics and Light Conversion II

Kevin Sivula, Ecole Polytechnique Fédérale de Lausanne (Switzerland)

4 Nanostructures and Nanowires

Natalie Banerji, Ecole Polytechnique Fédérale de Lausanne (Switzerland)

5 Collection of Charge Carriers at Interfaces I

Natalie Banerji, Ecole Polytechnique Fédérale de Lausanne (Switzerland)

6 Collection of Charge Carriers at Interfaces II

Carlos Silva, Université de Montréal (Canada)

7 Charge Transport in Organic Electron Devices

Carlos Silva, Université de Montréal (Canada) 
8 Unique Properties of Extended Conjugated Systems

Sophia C. Hayes, University of Cyprus (Cyprus)

9 Fundamental Materials Properties in Organic Photovoltaic Devices I Natalie Banerji, Ecole Polyłechnique Fédérale de Lausanne (Switzerland)

10 Fundamental Materials Properties in Organic Photovoltaic Devices II Natalie Stingelin-Stutzmann, Imperial College London (United Kingdom)

11 Charge Generation in Organic Solar Cells I

David G. Cooke, McGill University (Canada)

12 Charge Generation in Organic Solar Cells II

Garry Rumbles, National Renewable Energy Laboratory (United States)

13 Charge Generation in Organic Solar Cells III

Anna Kohler, Universität Bayreuth (Germany)

14 Charge Generation in Organic Solar Cells IV

Laurens D. A. Siebbeles, Technische Universiteit Delft (Netherlands) 